Marko Babić

\title{
Węzeł gordyjski: piętnaście lat daytonowskiej Bośni i Hercegowiny
}

Piętnastoletnie doświadczenie daytonowskiej Bośni i Hercegowiny (BiH) pokazuje, że różni się ona od innych krajów regionu przechodzących proces transformacji ustrojowej. Po pierwsze, nie było klasycznej transformacji z systemu komunistycznego do systemu parlamentarnej demokracji. Po drugie, nie było fazy klasycznej liberalizacji, ponieważ wkrótce po pierwszych wielopartyjnych wyborach parlamentarnych doszło do konfliktu zbrojnego. Nie można więc mówić o przebiegającym $\mathrm{w}$ sposób równomierny i ciagły procesie transformacyjnym i dlatego należy postrzegać społeczeństwo tego kraju jako postkonfliktowe, ale nadal przedtransformacyjne. Demokracja w takim kraju charakteryzuje się politykierstwem opartym na etniczności, dyskursem konfrontacyjnym, naciskami na media, stronniczościa prasy, instytucjonalnym i reformatorskim patem, zapalczywą retoryką i permanentnym kryzysem politycznym.

$\mathrm{Z}$ drugiej strony, kraj ten spełnia formalne warunki demokracji: odbywaja się wolne wybory parlamentarne, istnieje system wielopartyjny, także regulacje prawne zapewniające istnienie wolnych mediów, wolności zrzeszania się i wolności wypowiedzi, dostępu do informacji publicznej itp. Ale jest to demokracja nie mająca metafizycznej substancji toposu politycznego: brak aktywnego i świadomego uczestnictwa obywateli w procesach politycznych, brak odpowiedzialności politycznej zarówno poziomej, jak i pionowej, brak prawdziwej wolności mediów, podczas gdy dyskurs publiczny i dialog polityczny motywowane sa prawie wyłącznie tematami zastępczymi lub tematami ad hoc.

Społeczeństwo Bośni i Hercegowiny nie jest społeczeństwem odpowiedzialnym. Odpowiedzialność w tym kontekście rozumiem jako kontrolę ${ }^{1}$ nad aktualnymi procesami społecznymi i zdolność do antycypowania przyszłych. Istnieje rodzaj zgody między teoretykami społeczeństwa a praktykami, że odpowiedzialne społeczeństwo to takie, którego elita jest w stanie podejmować decyzje strategiczne zgodnie z potrzebami społecznymi i wziąc za nie odpowiedzialność. Jest także niezależna od zewnętrznych wpływów w procesie planowania i swoją aktywnościa zapewnia istnienie społeczeństwa wolnych jednostek. Faktem jest, że elita

${ }^{1}$ Rozumiana jako swoista „własność” nad teraźniejszościa. Por. D. Boaz, Defining an Ownership Society, http://www.cato.org/special/ownership_society/ boaz.html; zob. także http://georgewbush-whitehouse.archives.gov/news/releases/ 2004/08/20040809-9.html. 
polityczna w Bośni i Hercegowinie nie kontroluje teraźniejszości, także nie wygląda na to, że stanie się zdolną i sprawna, by umożliwić własnemu społeczeństwu stanie się „odpowiedzialnym” w najbliższej przyszłości.

Jeżeli przypomnimy sobie w skrócie historię ostatnich piętnastu lat, możemy stwierdzić, że od 1995 r. Bośnia i Hercegowina jest własnością wspólnoty międzynarodowej: pokój został osiagnięty dzięki zaangażowaniu międzynarodowej koalicji wojskowej z USA na czele; konstytucję Bośni i Hercegowiny, będąca częścia integralną porozumienia pokojowego (Aneks IV) napisali eksperci zagraniczni; gwarantami implementacji porozumienia pokojowego były najpierw $\mathrm{IFOR}^{2}$, następnie $\mathrm{SFOR}^{3}$ i później EUFOR ${ }^{4}$; proces demokratyzacji wraz $\mathrm{z}$ organizacją wyborów prowadziła $\mathrm{OBWE}^{5}$; stabilnością fiskalną państwa opiekowały się Bank Światowy i Międzynarodowy Fundusz Walutowy; Biuro Wysokiego Przedstawiciela $(\mathrm{OHR})^{6}$ personifikuje całościową aktywność międzynarodową i odpowiedzialność w Bośni i Hercegowinie, wzmocnioną poprzez tzw. uprawnienia bońskie dla Wysokiego Przedstawiciela z 1997 r. Dzięki tym uprawnieniom Biuro Wysokiego Przedstawiciela podjęło ponad 900 decyzji, które w najbardziej bezpośredni sposób substytuowały ingerencje lokalnych instytucji w dziedzinach strategicznych: w kwestiach konstytucyjnych, reform gospodarczych i sądowniczych, regulacji medialnych i w kwestiach majątkowych? W sytuacji braku efektywnych instytucji państwa Bośni i Hercegowiny, Biuro Wysokiego Przedstawiciela zostało zarówno substytutem, jak i sponsorem słabej biurokracji państwowej. Nalegając na przyjęcie wielkiej liczby reform, jednocześnie nie widzac, że w wielu obszarach reformy te nie zostały zinstytucjonalizowane w sposób znaczący, Biuro Wysokiego Przedstawiciela wykreowało instytucjonalną iluzję i pomniejszyło wartość pojęcia „własnośs"”.

${ }^{2}$ IFOR były operacją NATO prowadzoną w Bośni i Hercegowinie od 20 grudnia 1995 r. do 20 grudnia $1996 \mathrm{r}$.

${ }^{3}$ SFOR działały w ramach operacji ,Joint Guard” (od 21 grudnia 1996 r. do 19 czerwca 1998 r.) i ,Joint Forge" (od 20 czerwca 1998 r. do 2 grudnia 2004 r.).

${ }^{4}$ EUFOR to misja pokojowa prowadzona przez Unię Europejską w Bośni i Hercegowinie, rozpoczęta w 2004 r., zastępująca wycofujące się wojska NATO (misja SFOR).

${ }^{5}$ Por. http://www.oscebih.org/Default.aspx?id=0\&lang=EN.

${ }^{6}$ Biuro Wysokiego Przedstawiciela w Bośni i Hercegowinie zostało utworzone w 1995 r., zaraz po zawarciu porozumienia w Dayton. Jego głównym celem jest nadzorowanie i kontrola implementacji cywilnych ustaleń z Dayton. Wysoki Przedstawiciel i Biuro Wysokiego Przedstawiciela reprezentuja społeczność miedzynarodowa oraz ONZ. Wysoki Przedstawiciel jest jednocześnie Specjalnym Przedstawicielem Unii Europejskiej. Od 1995 r. następujący Wysocy Przedstawiciele sprawowali swój urząd: Carl Bildt (Szwecja) - 1995-1997; Carlos Westendorp (Hiszpania) - 1997-1999; Wolfgang Petritsch (Austria) - 1999-2002; Paddy Ashdown (Wielka Brytania) - 2002-2006; Christian Schwarz-Schilling (Niemcy) 2006-2007; Miroslav Lajčák (Słowacja) - 2007-2009; Valentin Inzko (Austria) - 2009-

${ }^{7}$ Zob. http://www.ohr.int/decisions.htm

${ }^{8}$ Notabene, ten wirtualny sukces w odbudowie instytucji państwowych był wykorzystywany w celu usprawiedliwiania wniosków o zmniejszenie uprawnień Wysokiego Przed- 
System władzy dzisiejszej Bośni i Hercegowiny był częścią planu pokojowego z Dayton, który to plan rzeczywiście zatrzymał działania wojenne i przyniósł pokój. Daytonowski system władzy na poziomie centralnym od początku nie przewidywał uformowania się silnego i dobrze funkcjonującego zarówno rządu, jak i systemu instytucji centralnych. Jego istotą było nie dopuścić do sytuacji, w której większość decyduje kosztem i na szkodę pozostałych narodów w Bośni i Hercegowinie. Dlatego dzisiaj mamy do czynienia z sytuacja, w której instytucje państwa Bośni i Hercegowiny nie mają zdolności nawet nadążać za dynamiką reform, które narzuca wspólnota międzynarodowa, np. poprzez Biuro Wysokiego Przedstawiciela. Przegląd najważniejszych problemów systemu instytucjonalnego tylko potwierdza te spostrzeżenia: państwowym instytucjom w Bośni i Hercegowinie brakuje niezależności, $\mathrm{z}$ jakiej korzystają rządy centralne $\mathrm{w}$ innych zdecentralizowanych państwach, i dlatego nie jest w stanie wykonywać swoich podstawowych funkcji: możliwość zastosowania etniczno-terytorialnego weta na poziomie centralnym wraz ze skomplikowanym podziałem uprawnień między państwem a entitetami ${ }^{9}$ (których notabene funkcjonalność zależy od wysokiego poziomu współpracy) poważnie ograniczają instytucje państwowe w realizacji swoich zadań. Poza tym, liczba instytucji państwowych poziomu centralnego, mających wyłączną jurysdykcję w swoim obszarze, jest bardzo mała. W innych obszarach budowa poziomu centralnego wymusiła przekazanie tylko części uprawnień z poziomów niższych na wyższy poziom, niemniej pozostał złożony system podzielonych uprawnien, których funkcjonowanie w dużej mierze jest uzależnione od dobrej woli licznych i różnych poziomów władzy. W tych obszarach

stawiciela oraz przeniesienie wszelkiej odpowiedzialności na instytucje Bośni i Hercegowiny. W ten sposób ignorowano brak instytucjonalnych zdolności i trwałości w Bośni i Hercegowinie, ale także fakt, że jakiekolwiek nagłe przeniesienie procesu reform na instytucje państwowe mogłoby spowodować implozję biurokratyczna.

9 Łac. ens, entis - byt, istnienie, jestestwo; franc. entité - (filoz.) istota. Według Porozumienia z Dayton, Bośnia i Hercegowina jest podzielona na dwa entitety: Republikę Serbska (49\% terytorium) i Federację Bośni i Hercegowiny (muzułmańsko-chorwacka) $51 \%$ terytorium. W tym kontekście termin „entitet” pozostaje z punktu widzenia prawnoustrojowego nieprecyzyjny. Wydaje się, że to właśnie było intencją twórców samego Porozumienia z Dayton - stworzenie daleko idacego kompromisu, który wszyscy będa w stanie zaakceptować. Tekst Porozumienia jest na tyle ogólny, a w niektórych przypadkach nieprecyzyjny, po to, by w momencie ponownego zaistnienia silnych bodźców integracyjnych był w stanie dostosować sie do nowej państwowo-politycznej sytuacji. Tak należy tłumaczyć i nazewnictwo części składowych $\mathrm{BiH}$. To nie sa ani republiki, ani regiony, ani autonomiczne obszary. Nazwano je entitetami, czyli „bytami”, lecz co to oznacza w sensie prawnoustrojowym, pozostawiono każdej ze stron do tłumaczenia według własnych preferencji. Potwierdzeniem tezy o intencjach twórców Porozumienia, antycypujacych przyszłe czasy i zmiany świadczy stwierdzenie, że wszystko, co nie jest w domenie BiH, należy do entitetów - por. M. Babić, Bośnia i Hercegowina - specyfika systemu politycznego, [w:] Małe państwa Europy. Specyfika systemu politycznego i aktywności międzynarodowej, red. nauk. D. Popławski, Warszawa 2009, s. 241. 
państwo pozostało poważnie zmarginalizowane. Pomimo tego, że ma swoją rolę w ustalaniu polityki, szczególnie zaś w relacjach i standardach między jednym a drugim entitetem oraz wobec umów międzynarodowych, entitety nadal posiadaja moc prawną $\mathrm{w}$ przypadku uprawnień podzielonych i często działają wbrew prawu państwowemu. Liczba konsultacji, ale i koordynacji oraz współpracy pomiędzy poszczególnymi poziomami władzy jest bardzo niska w kwestiach planowania i strategii (dotyczy to zwłaszcza kwestii dotyczacych procesu integracji europejskiej). Informacje te zatrzymywane są celowo. Ta obstrukcja jest zarówno polityczna, jak i administracyjna, i dotyczy braku poszanowania dla autorytetu państwa w obu entitetach. Instytucje państwowe najskuteczniejsze sa w tych obszarach, w których posiadają wyłączność (czyli tych, w których potrzeba współpracy $\mathrm{z}$ entitetami jest doprowadzona do minimum) oraz w sytuacji, gdy wysiłki międzynarodowe (OHR i innych instytucji międzynarodowych) nie koncentruja się wyłącznie wokół legislacji, ale polegają także na tworzeniu planów realizacji ${ }^{10}$.

Z drugiej strony, w sytuacjach, w których państwo ustala normy prawne (ramowe), a entitety posiadaja prawo do uchwalania i realizacji tych norm, państwowa legislatywa respektowana jest w stopniu minimalnym (z wyjątkiem, kiedy zastosowanie danych norm warunkowane jest agresywną interwencja czynnika międzynarodowego - bądź Wysokiego Przedstawiciela, bądź drogą dyplomatyczna). Tam, gdzie koordynacja bądź współpraca z entitetami wpisana jest $\mathrm{w}$ państwowy instytucjonalny schemat, nie układa się ona efektywnie z reguły ze względu na niemożność uzgodnienia decyzji pomiędzy różnymi poziomami decyzyjnymi. Powojenny proces odbudowy poziomu centralnego (czyli państwowego) instytucji w Bośni i Hercegowinie odbywa się na zasadzie „instytucjonalnego rozwarstwiania” 11 . Umożliwia to koegzystencję przedwojennych, wojennych i powojennych instytucji, których mandaty i uprawnienia poważnie się przekładaja. Żeby można mówić o funkcjonowaniu, siatka takich przekładanych i wzajemnie zależnych organów władzy wymaga wysokiego stopnia woli politycznej i konsensusu. Jeżeli tych warunków zabrakło, wówczas wspólnota międzynarodowa była tą instancja, spoiwem, które ten system powiązań w większym lub mniejszym stopniu utrzymywała w całości.

Wydaje się, że przez cały okres daytonowskiej Bośni i Hercegowiny ani lokalni politycy, ani urzędnicy międzynarodowi pracujacy $\mathrm{w}$ tym kraju nie uświadomili sobie, bądź nie chcieli sobie uświadomić, że efektywna administracja publiczna jest krytycznym segmentem w procesie budowy państwa. Dlatego kolejne próby reformy administracji publicznej spełzły na niczym. Próby reformy

${ }^{10}$ Strukture upravljanja državom u BiH. Jačanje institucionalnih kapaciteta i preuzimanje vlasništva nad promjenama u procesu integracije u EU, do funkcjonalne države, Sarajevo 2006, s. 13.

11 Tamże. 
nie obejmowały tak ważnych zagadnień, jak nieadekwatność zasobów ludzkich w administracji, przekładanie uprawnień (paralelizm), brak koordynacji pomiędzy różnymi poziomami władzy, istotny brak kompromisowej, kooperatywnej kultury zarządzania i wspólnej aktywności politycznej podczas zatrudniania urzędników państwowych i kierowania administracją publiczna. To tylko pogłębiło przepaść „etniczną" wewnątrz administracji publicznej. Dlatego istniejace status quo w administracji publicznej nadal w sposób poważny uniemożliwia jej funkcjonowanie, ale także odbiera wiarygodność instytucjom państwowym ${ }^{12}$.

Wykorzystywanie w złej wierze mechanizmów konstytucyjnych wykreowanych $\mathrm{w}$ celu zabezpieczenia sprawiedliwej etnicznej obecności w instytucjach państwowych obróciło się w sytuację imperatywu etnicznego, gdzie narodowe, a często nacjonalistyczne kryteria przynależności dominują w administracji publicznej. W ten sposób wytworzyła się - z jednej strony - nowa kasta Chorwatów, Serbów i Boszniaków - „odpowiednich” dla kluczowych stanowisk w służbie państwowej, a z drugiej strony - tych „wykluczonych”, czyli takich, którzy nie godzili się na przynależność do etnicznych ośrodków władzy politycznej. Nadużycia konstytucyjnych pryncypiów reprezentacji etnicznej oraz przekształcenie takiej polityki zatrudnienia do poziomu niemal doktrynalnego spowodowało prawdziwą implozję funkcji w administracji publicznej. Dzieje się tak, ponieważ system decyzyjny w Bośni i Hercegowinie uzależniony jest od woli politycznej elit. Można powiedzieć, że elity polityczne w sposób znaczący decydują o (nie)funkcjonalności państwa. Wykorzystały one wyżej wspomniany system w ten sposób, że zmonopolizowały i zagospodarowały przestrzeń publiczna na tyle, że nie pozostawiaja miejsca dla innych, niezależnych aktorów. Przestrzeń polityczna w Bośni i Hercegowinie nasycona jest interesami elit politycznych, które podporządkowują sobie także interes publiczny, utożsamiając go ze swoim własnym. Prowadzi to do nadmiernej i niepotrzebnej polityzacji większości zagadnień interesu publicznego - nawet tych, które z natury swojej nie są polityczne, ale pragmatyczne.

Elita polityczna w Bośni i Hercegowinie to grupa osób na stanowiskach kierowniczych $\mathrm{w}$ społeczeństwie, utrzymująca się u władzy dzięki temu, że jest swoista formą społeczno-politycznej awangardy wywodzącej się z czasów komunistycznych ${ }^{13}$, tym razem jednak mająca legitymację demokratycznoplebiscytarna, a także dzięki „formule politycznej” etnonacjonalizmu jako dominującej interpretacji egzystencji politycznej. Czy zatem nie należałoby mówiąc o elitach politycznych Bośni i Hercegowiny - używać tego terminu

12 Tamże, s. 14.

${ }^{13} \mathrm{~W}$ sensie konceptualnej kontynuacji reprodukcji elit w zgodzie z zasadami kolektywistycznej reprezentacji oraz politycznej awangardy elit jako swoistego „partyjnego" podmiotu. 
w liczbie pojedynczej, bez względu na linię istniejącego podziału przynależności etniczno-narodowej? Produkcja konfliktu generowanego w głównej mierze przez elity polityczne, usankcjonowane pełnym poparciem mas do prowadzenia „interesów narodowych”, stała się jednym z najważniejszych mechanizmów społecznych, który legitymizował reprodukcję elit politycznych. Produkcja wroga posłużyła jako epistemologiczna podstawa definiowania problemu społecznego, którego rozwiązaniem miała zająć się właśnie elita polityczna ${ }^{14}$. Ugo Vlaisavljević stwierdził: „Po podpisaniu układu pokojowego z Dayton, Bośnia i Hercegowina stanowi "społeczeństwo» w stanie wyjątkowym. A jeśli zapytamy, któż to taki stanowi zagrożenie dla dawnego społeczeństwa proletariackiego, złożonego z wielu grup etnicznych, a zarazem dla współczesnych wspólnot etnicznych w Bośni, najkrótsza odpowiedź w obu przypadkach może brzmieć: śmiertelny wróg z poprzedniej wojny. Gdyby dawni wrogowie nie byli groźni jeszcze długo po wojnie, większości ludzi nie interesowałyby historie wojenne. Etniczna narracja straciłaby swoją grupę docelowa, tj. słuchaczy obawiających się o własne życie, i utraciłaby główny kanał dla swojego międzypokoleniowego przekazu. Entropia narracyjna poważnie zagraża istnieniu narodu etnicznego. Warunkuje go ciagłe poczucie zagrożenia. Nieustająca świadomość obecności wroga urealnia krążące opowieści wojenne, a opowieści wojenne ze swej strony mają za cel wytwarzać ową świadomość. Nie wiadomo, co dla przywódców narodu, wpływowych polityków i ideologów, jest ważniejsze: opowiadanie historii wojennych czy ujawnienie faktu, że podstępni wrogowie czekają na właściwy moment, by zaatakować"15. A zatem zdefiniowanie wspólnego wroga przedstawia trwała formę procesu odnawiania kierowniczej legitymacji dzisiejszych elit politycznych. Konflikt jest jednym z najważniejszych mechanizmów generujących ich istnienie w Bośni i Hercegowinie. Konflikt i wróg, jako kluczowe pojęcia rozumowania politycznego w filozofii Carla Schmitta, są także w środku „formuły politycznej” elit politycznych w daytonowskiej Bośni i Hercegowinie, które w ten sposób usprawiedliwiaja swoją egzystencję. Wszystko zatem co „polityczne”, naznaczone jest konfliktowym charakterem stosunków politycznych, utrzymujących wyraźne podziały wzdłuż linii etniczno-narodowej przynależności.

Elity polityczne i ustrój polityczny Bośni i Hercegowiny są wzajemnie powiązane. Dlatego dekonstrukcja systemu politycznego, także jego jądra instytucjonalnego, nie jest możliwa bez dekonstrukcji „formuły politycznej”, która legalizuje ich istnienie. Niewiele jest społeczeństw politycznych na świecie, których elity do tego stopnia są powiązane i wzajemnie zależne od systemu

${ }^{14}$ N. Ćurak i in., Politička elita u Bosni i Hercegovini i Evropska Unija: odnos vrijednosti, Sarajevo 2009, s. 46

${ }_{15}$ U. Vlaisavljević, Bośnia $i$ Hercegowina: ciagłość etnopolityki w wieku integracji europejskiej, [w:] Rok 1989 - 20 lat później. Kraje postkomunistyczne a integracja europejska, Warszawa 2009, s. 163. 
politycznego, jak ma to miejsce w Bośni i Hercegowinie. Można stwierdzić, że elita polityczna tworzy podstawy systemu politycznego. A nawet system polityczny jako taki - między struktura polityczna społeczeństwa sformułowana w konstytucji państwa a elitą polityczną w dużej mierze stoi znak równości. W tym sensie wszelkie reformy polityczne w Bośni i Hercegowinie sa niemożliwe bez zmiany położenia, statusu i sposobu reprodukcji elit politycznych. Każda zmiana, która nie spowoduje dekonstrukcji dominującej elitystycznej formy, będzie jedynie symulacją rozwoju demokratycznego społeczeństwa Bośni i Hercegowiny ${ }^{16}$.

Przypadek monopolizacji procesu politycznego ze strony elit politycznych w literaturze określa się mianem demokracji „zapchanej” elitami (elite-packed democracy $)^{17}$. Według Larry'ego Diamonda w takiej demokracji partie polityczne monopolizują proces polityczny i opanowuja państwowe i organizacyjne życie do tego stopnia, że pozbawiają inne grupy interesu i instytucje politycznej autonomii. Kilka takich charakterystyk mamy w elite-packed Bośni i Hercegowiny. Istnieje głęboki podział między społeczeństwem politycznym a społeczeństwem obywatelskim. Elity polityczne przedstawiaja siebie jako obrońców procesu politycznego ${ }^{18}$. Zamiast przejać rolę „przewodnika” interesów publicznych w imieniu obywateli w stosunku do państwa, elity polityczne działaja jako „izolatorzy” między państwem a obywatelami. Dlatego nie uznają istnienia innych niezależnych aktorów życia politycznego, w tym społeczeństwa obywatelskiego, sądownictwa, mediów i są przeciwne ich niezależności. Dobrym tego przykładem były negocjacje $\mathrm{w}$ sprawie reform konstytucyjnych w bazie wojskowej Butmir koło Sarajewa w październiku 2009 r. Media i społeczeństwo obywatelskie zostały wykluczone z całego procesu - tylko liderzy partyjni i ich zespoły negocjacyjne miały monopol na informacje. W ten sposób mogli oni manipulować opinią publiczna, przepuszczając selektywnie tylko te informacje, na których im zależało. Berliński „Tageszeitung” pisał: „Załamanie się rozmów na temat nowelizacji konstytucji pod koniec października oznacza, że aparat państwowy w Bośni i Hercegowinie będzie miał jeszcze mniej władzy niż obecnie. Większe pole manewru zyskają z kolei nacjonaliści z mafijnym rodowodem, podejrzani przywódcy religijni i przekupni politycy na usługach potentatów przemysłowych, którym łatwiej będzie w dalszym ciagu manipulować bezsilnymi i zubożałymi obywatelami zdanymi na łaskę i niełaskę możnych”19. Dlatego termin „elity polityczne” w kontekście demokracji w Bośni i Hercegowinie wymyka się poza

${ }^{16}$ N. Ćurak i in., $d z$. cyt., s. 48.

${ }^{17}$ Por. L. Diamond, Elite packed democracy, [w:] Developing Democracy: Toward Consolidation, Baltimore 1999

18 Proces polityczny rozumiany jako rozciagnięta w czasie sekwencja (ciag) zachowań i zdarzeń, które powodują zmianę zakłócająca lub przywracająca równowage systemowi politycznemu - por. A. Antoszewski, Proces i zmiana polityczna, [w:] Studia z teorii polityki, red. A. Jabłoński i L. Sobkowiak, t. I, Wrocław 1996.

${ }^{19} \mathrm{http}: / /$ www.presseurop.eu/pl/content/article/139741-zagrozona-demokracja. 
definicje akademickie, ponieważ pojęcie to obejmuje także bardzo wpływowe osoby, niekoniecznie należące do elit politycznych w sensie formalnym. Z drugiej strony sa osoby, które formalnie należą do kategorii elit, ale posiadaja bardzo niewielkie realne wpływy polityczne. Przykładem tych ostatnich sa w dużej mierze ustawodawcy na różnych szczeblach władzy, którzy poza możliwościa uchwalania ustaw maja bardzo małe wpływy polityczne poza parlamentem. Jednak to pierwsza grupa stanowi o specyfice życia politycznego w Bośni i Hercegowinie. To sieć osób nie będących częścią formalna życia politycznego, ale zasiadajacych w nieformalnych, lecz wpływowych pozainstytucjonalnych kręgach politycznych. Do takiej grupy należą także ludzie biznesu (czasami z wątpliwą przeszłościa, których interesy zależą w dużym stopniu od wsparcia pewnych elit politycznych). To także członkowie społeczności akademickiej, którzy wspierają konkretne projekty o charakterze ideologicznym, przywódcy religijni, właściciele mediów i dziennikarze, przedstawiciele środowisk przestępczych itd. Sprzyja to budowaniu państwa, w którym demokratyczne reguły gry jeszcze nie istnieją ${ }^{20}$.

Wszechobecne w życiu publicznym elity polityczne są w pozycji, z której kreuja opinię publiczna, klimat i dyskurs publiczny. Staje się to coraz bardziej zauważalne od momentu, kiedy potentaci medialni zostaja politykami, a niektórzy politycy staja się formalnymi lub nieformalnymi właścicielami niektórych mediów. Rozszerza to jeszcze bardziej proces polityzacji szerokiego spektrum zagadnień gospodarczych, społecznych, technicznych, kulturowych, sportowych itd. Przedmiotem etnicznej polaryzacji stała się nawet budowa najważniejszej linii komunikacyjnej pod nazwą „Korydor Vc”, czyli europejskiej trasy E-75 łączącej północ z południem, biegnącej przez środkowe Węgry, wschodnią Chorwację (Slawonię) oraz wschodnią Bośnię i Hercegowinę przez Šamac, Doboj, Zenicę, Sarajewo i Mostar. Zamiast być katalizatorem konsensusu na wszystkich szczeblach władzy, budowa tej niezwykle ważnej gospodarczo drogi przedstawiana jest w opinii publicznej jako zagrożenie dla interesów narodowych poszczególnych narodów. W istocie chodzi o spór, która $\mathrm{z}$ elit etnicznych ma więcej ziemi w posiadaniu, przez która ma przebiegać przyszła droga E-75 (,Korydor Vc”) ${ }^{21}$.

Prywatyzacja wpływu politycznego jako zasada podejmowania decyzji „przenosi” system podejmowania decyzji poza oficjalne instytucje. Taki stan rzeczy pozbawia wspólnotę międzynarodową poważniejszego wpływu na system polityczny, także zmniejsza wpływ społeczeństwa obywatelskiego na państwo z korzyścią dla nieformalnych czy prywatnych interesów. Dlatego często się zdarza, że właściwym adresatem przy podejmowaniu decyzji w sprawie kluczowych reform nie

${ }^{20}$ Dlatego funkcjonalność, ale i przetrwanie państwa zależeć będzie od zmian istniejących reguł gry i stworzenia systemu niezależnego od woli elit politycznych i interwencji międzynarodowych. Wspólnota międzynarodowa w ciagu ostatnich piętnastu lat nie stworzyła swojego następcy - struktur zdolnych do samodzielnego funkcjonowania.

${ }^{21}$ Szczególnie dotyczy to części trasy przebiegającej przez Hercegowinę. 
są członkowie parlamentu, ale szefowie partii, a nawet osoby, które formalnie nawet nie są członkami partii politycznych ${ }^{22}$. Zjawisko to można również określić jako tworzenie polityczno-etniczno-ekonomiczno-religijno-finansowej sieci, która jest silniejsza niż wszelkie formalne struktury instytucjonalne w Bośni i Hercegowinie. Tajemniczość owych stosunków służy ukrywaniu prawdziwych źródeł wpływów. Jednocześnie zwiększa to siłę elit politycznych w przeciwstawianiu się presji międzynarodowej, ale i społeczeństwa obywatelskiego. Fakt, że źródła wpływów politycznych znajdują się poza formalnymi strukturami demokratycznymi, zmniejsza także poczucie odpowiedzialności demokratycznie wybranych urzędników. Tworzy to niewyraźny podział odpowiedzialności (czyli kto przed kim odpowiada i za co), co podważa samo pojęcie odpowiedzialności wobec społeczeństwa. W tym kontekście, w którym te najważniejsze parametry stanowia podstawę do reprodukcji i funkcjonowania elit politycznych, nie jest zaskakujące, że ta grupa społeczna jako grupa bardzo wpływowych osób nie ma poczucia odpowiedzialności publicznej, a więc nie czuje potrzeby, aby zgodnie z liberalno-demokratycznymi zasadami politycznymi uzasadniać własną działalność w sferze publicznej. Nie istnieje koncept odpowiedzialności politycznej, jaki istnieje w krajach rozwiniętej demokracji liberalnej, w których osoby na kluczowych stanowiskach politycznych pierwsze ponoszą odpowiedzialność za swoją działalność. W Bośni i Hercegowinie w ciągu ostatnich piętnastu lat nie zanotowano ani jednego przypadku, w którym dana osoba sprawująca władzę zrezygnowałaby wskutek niepowodzenia własnej polityki czy skandalu ${ }^{23}$.

Jednocześnie, społeczne oczekiwania wobec elit politycznych sa na bardzo niskim poziomie, ponieważ wiadomo, że ośrodki władzy znajdują się gdzie indziej, więc nikt nie uważa ich za odpowiedzialne i dlatego nikt nie pociaga do odpowiedzialności formalnych elit politycznych. Tak niskie oczekiwania wobec systemu demokratycznego tworzą klimat polityczny, w którym każde działanie, bez względu jak niedemokratyczne, staje się społecznie akceptowalne. Ponieważ elity zawładnęły w pewnym stopniu także mediami, kontrolujacca rola mediów realnie nie istnieje. Niezadowolenie z systemu politycznego nie zostaje przekształcone w działania publiczne, ale wywołuje poczucie apatii i rezygnacji, które następnie dodatkowo zmniejsza oczekiwania społeczeństwa. Wszelka krytyka elit politycznych z kolei uważana jest za irracjonalny akt odwagi lub po prostu za naiwność. Stąd m.in. niechęć wspólnoty międzynarodowej do ostrej reakcji na przejawy naruszeń demokratycznych zasad, jakie obserwowaliśmy w przeciagu ostatnich lat. Brak zarówno sankcji społecznych, jak i międzynarodowych tylko utwierdza społeczeństwo w przekonaniu, że elity są „nietykalne”. W sposób bezpośredni

${ }^{22} \mathrm{Na}$ przykład podczas negocjacji w sprawie reformy policji to reis-ul-ulema Mustafa Cerić, przywódca religijny muzułmanów bośniackich, zwoływał spotkania liderów politycznych, i w ten sposób pragnął wpływać na przebieg tych negocjacji.

${ }^{23}$ N. Ćurak i in., dz. cyt., s. 47. 
potwierdza ten stan rzeczy bardzo niski stopień zaufania społecznego w Bośni i Hercegowinie oraz zaufania obywateli do instytucji jako źródła władzy elity politycznej. Jak wynika z niektórych badań przeprowadzonych w ciagu ostatnich lat, poziom zaufania do instytucji politycznych pozostaje bardzo niski. Według badania przeprowadzonego w $2007 \mathrm{r}$. ponad $80 \%$ ludności nie ma zaufania do partii politycznych, mniej niż $80 \%$ do instytucji państwowych, ponad $60 \%$ nie ufa organizacjom międzynarodowym, sądom, a mniej niz $60 \%$ nie ma zaufania do instytucji entitetów. Ciekawy wydaje się fakt, że większość obywateli (64\%) uważa, że urzędnicy $\mathrm{w}$ instytucjach państwowych są skorumpowani, chociaż większość (79\%) nigdy nie była w sytuacji wręczania pieniędzy za usługi. Wszystko to wpływa na fakt masowego nieuczestniczenia w procesach podejmowania decyzji politycznych. Badania $\mathrm{w}$ tym sensie potwierdzaja, że wśród krajów przechodzących okres transformacji ustrojowej Bośnia i Hercegowina ma najmniejszy odsetek wyborców zainteresowanych polityką (dokładnie 57\% osób w ogóle nie interesuje się polityka) ${ }^{24}$.

Złożony system podejmowania decyzji w BiH systematycznie zależy od woli elit politycznych i to tworzy zagrożenie dla trwałości systemu demokratycznego w Bośni i Hercegowinie. System podziału władzy został zaprojektowany, aby funkcjonować tylko, jeśli istnieje wystarczająca wola polityczna w każdym z trzech wymiarów - partyjnym, etnicznym i entitetowym. Brak konsensusu politycznego w obszarze któregokolwiek z tych trzech wymiarów może zablokować cały system podejmowania decyzji. Taki system nie motywuje przywódców politycznych do udziału w życiu politycznym w sposób konstruktywny. System pozwala, by niweczyli wzajemnie swoje projekty, co tylko stanowi zachętę do samodzielnego działania nieopartego na współpracy. Z jednej strony, na podstawie zapisów własnej konstytucji kieruja się wyłącznie interesem grupowym. Z drugiej zaś, sa zainteresowani utrzymaniem takiego społecznego i politycznego środowiska, które wskazuje, że społeczno-polityczną koniecznością sine qua non jest istnienie silnej elity politycznej. Instytucje państwowe nie maja odpowiednich uprawnień i autonomii działania, aby zmusić elity polityczne do odpowiedzialnego uczestnictwa $\mathrm{w}$ procesach decyzyjnych. $\mathrm{Z}$ tego powodu wiele rzeczywistych priorytetów strategicznych w Bośni i Hercegowinie nadal pozostaje określanych poprzez agendy międzynarodowe. Priorytety te pochodzą albo $\mathrm{z}$ wcześniejszych zobowiązań, takich jak zobowiązania $\mathrm{w}$ dziedzinie praw człowieka, podjęte ze względu na członkostwo w Radzie Europy, lub wynikaja z warunków podpisania Porozumienia o Stabilizacji i Stowarzyszeniu, a także dalszej integracji z Unią Europejską. Ze względu na upolitycznienie tych zagadnień i brak wspólnej wizji, w jaki sposób i dlaczego budować wspólne państwo, elity polityczne w Bośni i Hercegowinie doprowadzaja do takiej

${ }^{24}$ Wyżej wymienione dane można znaleźć w: The Silent Majority Speaks: Snapshots of Today and Visions of the Future of Bosnia and Herzegovina, Sarajevo 2007. 
polaryzacji stanowisk podczas negocjacji, że de facto skazuja je na niepowodzenie. Powoduje to kryzysy polityczne, które często są w stanie blokować działalność instytucji państwowych na wiele miesięcy.

Mimo piętnastu lat międzynarodowej obecności w Bośni i Hercegowinie, państwo to nadal pozostaje wyizolowane na arenie międzynarodowej $\mathrm{w}$ sensie formalnej integracji w szerszym, międzynarodowym środowisku (w takich strukturach, jak Unia Europejska i NATO). Z perspektywy możemy powiedzieć, że początkowy okres międzynarodowej interwencji w tym kraju (lata 1995-2000) był udany $\mathrm{w}$ kontekście zaprzestania rozlewu krwi, zaprowadzenia pokoju, a także przywrócenia niektórych funkcji państwa. W tym czasie społeczność międzynarodowa zaczęła opracowywać strategię pozwalającą na samodzielne funkcjonowanie państwa poprzez aktywne uczestnictwo lokalnych elit politycznych. Wprowadzenie „uprawnień bońskich” w grudniu 1997 r. miało na celu stworzenie takiego instrumentarium, za pomocą którego wspólnota międzynarodowa mogłaby zidentyfikować partnerów rzeczywiście dążących do realizacji postanowień Porozumienia Pokojowego z Dayton, gotowych do przejęcia sterów reform. Zwolnienia z pracy tych urzędników państwowych, którzy zostali uznani za niezainteresowanych bądź wrogo nastawionych do Porozumienia i jego postanowień, stworzyły wrażenie, że wszyscy pozostali autentycznie są zaangażowani $\mathrm{w}$ proces reform. Taka strategia tylko wzmocniła i dała legitymizację istniejącym elitom politycznym, głównie wywodzącym się z czasów konfliktu zbrojnego ${ }^{25}$. Należy jednak pamiętać, że istnieje normatywna niezgodność między systemami wartości Bośni i Hercegowiny i Unii Europejskiej. Dzisiejszy, dominujący system wartości w BiH jest zakorzeniony w ekskluzywizmie charakteru oraz naturze podziału struktur wywodzących się z Porozumienia z Dayton. Stoi to $\mathrm{w}$ otwartej sprzeczności $\mathrm{z}$ projekcją norm unijnych, mających zasadniczo charakter integracyjny. Powoduje to zarówno kulturowe, jak i normatywne zderzenia dwóch systemów lub dwóch społeczeństw, co kwestionuje potencjalną stosowalność norm i reguł unijnych w Bośni i Hercegowinie. Elity polityczne zainteresowane zachowaniem status quo będa odrzucać wszelkie wysiłki Unii Europejskiej prowadzące ku wewnętrznej integracji w celu ułatwienia przyszłej integracji Bośni z UE. Stwierdzić należy, że normy dominujące w Bośni i Hercegowinie stoją niejako w pozycji kontra wobec norm obowiązujących w Unii Europejskiej, takich jak: demokracja, prawa człowieka, wolności obywatelskie. Działaja one jednocześnie jako bariery uniemożliwiając przyjęcie norm bardziej demokratycznych. Jako przykład może posłużyć badanie stanowiska w sprawie integracji Bośni i Hercegowiny z UE - ponad 75\% mieszkańców opowiedziało się zdecydowanie za przystapieniem do Unii Europejskiej. Jednak wsparcie to spada

25 Szczególnie wybory z 1996 r., uznane za demokratyczne, pozwoliły zakorzenić się wojennym elitom w systemie politycznym, w pełni obsadzić przestrzeń polityczna, nie pozostawiając miejsca na nowe i świeże siły polityczne. 
prawie o połowę, gdy uzależnia się akcesję od spraw, które rzutują na kwestie uważane za „interes narodowy” (np. aresztowania zbrodniarzy wojennych bądź pomysł likwidacji entitetów). Poparcie zatem dla integracji z Unią Europejska istnieje tylko w stopniu, który nie narusza utrwalonych podziałów etnicznych.

W końcu, Unia Europejska nie wykorzystuje swojego pozytywnego wizerunku w celu ochrony i wspierania wartości demokratycznych. Na przykład zarówno w krajach Europy Środkowej, jak i w Słowenii oraz Chorwacji, istniało i istnieje poczucie „powrotu do Europy”, który spowodował znaczący wzrost poparcia opinii publicznej i entuzjazm społeczny dla integracji z UE. Faktem jest, że mamy wyraźny brak takiego poczucia „przynależności do Europy” w społeczeństwie Bośni i Hercegowiny, niemniej Unia nie oferuje żadnych alternatywnych propozycji, które pozwoliłyby państwu bośniackiemu poczuć się bliżej Europy ${ }^{26}$. Dla opinii publicznej w Bośni Unia Europejska jest zbyt odległa, zbyt abstrakcyjna i wydaje się być poza zasięgiem. Natomiast obawą elit politycznych jest nie pozostać jedynym krajem w regionie nienależącym do Unii bądź przynajmniej nie być ostatnim przyjętym. Nie ulega wątpliwości, że w Bośni i Hercegowinie nie ma silnej integracyjnej presji wewnętrznej i dlatego wydaje się, że taka presja powinna przyjść z zewnątrz - z Unii Europejskiej.

Istnieje jeszcze jedno niebezpieczeństwo. Polityka wojenna nadal prowadzona przez nacjonalistyczne (w większej lub mniejszej mierze) elity polityczne utrzymuje przy życiu dwie sprzeczne wizje, które doprowadziły do wybuchu konfliktu zbrojnego w 1992 r. - wizję Bośni i Hercegowiny jako podzielonego kraju oraz wizję unitarnego państwa. Porozumienie pokojowe $\mathrm{z}$ Dayton ani nie zaakceptowało, ani nie zaprzeczyło żadnej z tych dwóch wizji. Porozumienie nawet nie zaproponowało trzeciej opcji. Nadzieje pokładano w budowie instytucji państwa pod nadzorem międzynarodowym, majacych spowodować zanikanie tych sprzecznych ze sobą wizji. W roku 2011 wizje te nadal są żywe i grożą konfrontacją. Pozostaje tylko pytanie, jaką formę konfrontacji przybierze ów konflikt wizji i czy w ogóle instytucje państwa są przygotowane, by przetrwać ten konflikt.

$$
* * *
$$

System polityczny w Bośni i Hercegowinie, choć formalnie demokratyczny, nie funkcjonuje zgodnie $\mathrm{z}$ demokratycznymi regułami. Podział władzy, oparty na Porozumieniu z Dayton, polega na woli politycznej elit. Elity są w stanie skutecznie blokować funkcjonowanie systemu politycznego, ponieważ podstawa do jego funkcjonowania jest konsensus, którego osiagnięciem nie są zainteresowane. Elity polityczne zdominowały państwo, monopolizuja procesy polityczne, zawłaszczaja instytucje państwowe, które potem wykorzystuja jako platformę do swojej nieformalnej działalności. Prywatyzacja wpływów politycznych powoduje, że władza

${ }^{26} \mathrm{Na}$ ten temat zob. T.K. Vogel, Izvan fokusa. Neizvjesna evropska perspektiva Bosne $i$ Hercegovine, 2 VI 2009, http://www.pulsdemokratije.ba/index.php?l= bs\&id=1576. 
polityczna znajduje się poza instytucjami, co tworzy rozdźwięk między oficjalną i realna władzą polityczna, skutecznie oddalając kwestie odpowiedzialności. Społeczeństwo obywatelskie, choć świadome natury problemów, jest efektywnie blokowane samą logiką systemu, uniemożliwiajaca mu aktywną rolę polityczną w ewentualnych zmianach. W kontekście funkcjonalności instytucjonalnej, rzeczywistość Bośni i Hercegowiny można podsumować, cytując jednego z badaczy:

„W sensie konstytucyjnym - w państwie Bośni i Hercegowinie dominuje supremacja norm i decyzji międzynarodowych będacych ponad państwowym ustawodawstwem;

- w sensie administracyjnym - podzielona jest na entitety i kantony będące zaprzeczeniem tysiącletniej tradycji religijno-etnicznej koegzystencji, które «mutują» w kierunku multietniczno-nacjonalistycznej konkurencji;

- w sensie systemowym - kompleksy polityczne i administracyjne entitetów mają charakter parapaństwowy;

- w sensie ekonomicznym - zamiast własności prywatnej stymulującej wolny rynek, wykreowana została przestrzeń dla kryminogennych procesów prywatyzacyjnych;

- w sensie ideowym - Bośnia i Hercegowina z potencjalnej demokracji reprezentatywnej, której niepodległość została zakwestionowana (i dlatego wybuchł konflikt zbrojny), ewoluowała w kierunku «quasi-protektoratu» wspólnoty międzynarodowej, co otwiera pytanie o jurysdykcję nad nim"27.

Nie ulega wątpliwości, że w przypadku dalszego chronicznego instytucjonalnego paraliżu, z jakim mamy do czynienia, Bośni i Hercegowinie grozi rozpad. Alternatywą jej przetrwania może być (samo)izolacja i całkowity upadek gospodarczy. W najgorszym przypadku, powrót do stanu bezwładzy, niepewności i kolejnej wojny. Inna alternatywa mogłaby być sytuacja, w której dominacja przynależności etnicznej nie jest źródłem praw ogólnych jednostek, a tożsamości etniczne nie sa chronione konstytucyjnie jako wspólnoty tworzone jako parapaństwa ze szkoda dla innych para-państw (Republika Serbska contra Federacja Bośni i Hercegowiny i vice versa). Byłoby to możliwe poprzez wzmacnianie instytucji centralnych kosztem instytucji w entitetach, gwarantujaccych prawa indywidualne jednostkom jako obywatelom Bośni i Hercegowiny, a nie prawa kolektywne jako Chorwatom, Boszniakom czy Serbom.

Niestety, status elit politycznych w systemie politycznym (z systematyczna produkcją lęku przed dominacja jednej grupy etnicznej nad inna), niezdecydowane stanowisko wspólnoty międzynarodowej oraz - w konsekwencji - zmarginalizowana rola instytucji centralnych, pokazuja, że takie rozwiązanie, piętnaście lat po podpisaniu Porozumienia z Dayton, nie jest realne.

27 W. Oschlies, Das politische System Bosnien-Herzegowina, [w:] Die politischen Systeme Osteuropas, 2. Auflage, Hrsg. W. Ismayr, Opladen 2004, s. 764-765. 